\title{
TEMAS INTERDISCIPLINARES CONTEMPORÂNEOS
}

\section{EDITORIAL}

No segundo número deste ano da Revista Ciências Humanas, os artigos publicados reforçam o caráter interdisciplinar da revista que trata de temas de interesse acadêmico e social que ocupam a agenda contemporânea, inclusive sobre a pandemia provocada pela Covid 19. A pandemia alcançou todos os setores da vida social de um modo que para compreender suas consequências é necessário recorrer ao olhar interdisciplinar. Assim, ela emergiu como um dos temas interdisciplinares com maior destaque neste ano.

Dessa maneira, abrimos esta edição da Revista Ciências Humanas com a entrevista realizada com o Prof. Dr. Ruy Braga, especialista em Sociologia do Trabalho e professor titular do Departamento de Sociologia da Universidade de São Paulo (USP) sobre "Periferias, Pandemia e Precarização do Trabalho: uma análise da realidade brasileira sob a luz de aspectos econômicos, políticos e religiosos". A entrevista, realizada por Angela Michele Suave, Tatiana Aparecida Cleto Oliveira Tardelli e Elisa Maria Andrade Brisola, foi um desdobramento do segundo Seminário Interdisciplinar do Mestrado em Desenvolvimento Humano/UNITAU de 2020, em que o entrevistado foi palestrante.

Além da entrevista e de um ensaio o número é composto por dez artigos. O artigo "Cidades Criativas da Unesco no Brasil: uma pesquisa exploratória sobre o comportamento do poder público na implementação de estratégias e estratégias voltadas à economia da cultura durante a pandemia provocada pela covid-19", es- crito por Marcelo Ferreira de Sousa, Adilson da Silva Mello e Lauren Ferreira Colvara, discute sobre as ações promovidas pelas cidades que compõe tal rede, retratando diferentes comportamentos do poder público e aspectos que demonstram atuações com baixo impacto na garantia de seguridade e fomento da economia e cultura durante as dinâmicas transformações do mercado provocadas pelo isolamento social.

Em seguida, o texto "Investigating the Spatial Organization Traditional Neighborhoods of Hamedan and its Impact on Social Relations", de Zahra Jamebozorg, Araz Najafi e Zarrin Fakhar, propõe reflexão sobre as mudanças ao longo dos planos de desenvolvimento da cidade e da sua estrutura tradicional que impactaram na funcionalidade e no nível de comunicação entre os moradores dos bairros tradicionais de Hamedan. Enquanto isso, o estudo "Prevendo o medo do crime: evidências a partir de um bairro maceioense", de Fillipi Lúcio Nascimento e Jairo da Silva Gomes, aborda fatores associados ao medo do crime expresso pela população do bairro maceioense de Benedito Bentes, 0 maior bairro da capital alagoana.

Este número também traz discussão sobre questões políticas e políticas sociais. $\mathrm{O}$ artigo "Candidatos "na" Região e Candidatos "da" Região: campanhas políticas no Vale do Paraíba/ SP", de Carlos Eduardo Pinto Procópio, Sidney Jard da Silva, André Luiz da Silva e Gilson Nascimento de Oliveira, analisa quatro campanhas eleitorais para deputado estadual e federal no pleito de 2014 no Vale do Paraíba paulista. 
Por sua vez o texto "A Política de Cotas: mecanismo democrático de acesso ao ensino superior público", escrito por Tamirys Meirielle Marques e Rogério Rodrigues, mostra que a política de cotas e as ações afirmativas surgiram como meio de contribuir para a igualdade de oportunidades e vêm cumprindo o proposto, na medida em que proporcionam o acesso de uma parcela de estudantes antes excluídos desse espaço de conhecimento, que é a universidade.

Na sequência, o texto "Precisamos falar sobre thanos!", de Jander Fernandes Martins, propõe uma reflexão, a partir do filme Avengers: Infinity War, sobre como e por quê uma franquia de renome elegeu como "pano de fundo" de sua trama ficcional, o ideário de Thomas Malthus (1766-1834). A revisão integrativa da literatura "O Conceito de Precariedade e as Contribuições Teóricas de Judith Butler para a Compreensão da Prática Política da Psicologia", proposta por Francisco Francinete Leite Junior, Maria Cristina Lopes de Almeida Amazonas e Hermógenes Abraão Paz Siqueira, aponta que o uso deste conceito não se restringe ao campo da Psicologia, mas, ainda assim, pode contribuir com o desenvolvimento desta ciência enquanto campo teórico e prático.

O olhar interdisciplinar para inovação, ensino e educação também teve espaço nesta edição. 0 estudo "Percepções e contribuições da formação continuada na voz dos docentes da Educação Infantil", de Daniela Cristina Beraldo dos Santos Silva e Maria
Aparecida Campos Diniz, teve como objetivo identificar e compreender a visão das docentes atuantes na Educação Infantil, no que tange à formação continuada e em serviço da qual participam e se esta contribui ou não para a sua profissão. No texto "DESIGN THINKING E DESIGN SPRINT: metodologias possíveis para a Educação Integral e para o desenvolvimento das competências socioemocionais aplicadas ao Ensino da Sociologia", Leonardo Gonçalves Ferreira e Kenya Marcon analisam como as novas metodologias podem auxiliar a Educação Integral no desenvolvimento das competências socioemocionais.

O estudo de revisão "Marketing em clusters e APL: análise bibliométrica das publicações nacionais no período de 2009 a 2019", proposto por Vailson Batista de Freitas e Silvio Augusto Minciotti, analisa as publicações científicas sobre clusters e arranjos produtivos locais (APLs) no Brasil, que abordam o tema Marketing. Para encerrar a edição, o ensaio teórico sobre "Agrotóxicos: uma breve reflexão para um problema complexo", escrito por Carlos Alberto Mourão Júnior e Charles Adriano Duvoisin, propõe um diálogo com o leitor e fomenta a reflexão crítica sobre o tema.

Agradecemos aos autores por sua contribuição para as discussões e reflexões acerca da temática interdisciplinar e aos pareceristas pela possibilidade de lançar essa edição e desejamos uma excelente leitura a todos!
Alexandra Magna Rodrigues Editora chefe da Revista Ciências Humanas

Rachel Duarte Abdala Editora executiva da Revista Ciências Humanas

\section{ID ORCID IDS}

Rodrigues AM - https://orcid.org/0000-0001-7143-3258

Abdala DR - https://orcid.org/0000-0002-6936-5329 